Soares-Filho, B., Moutinho, P., Nepstad, D., Anderson, A., Rodrigues, H., Garcia, R. et al. (2010) Role of Brazilian Amazon protected areas in climate change mitigation. Proceedings of the National Academy of Sciences of the USA, doi 10.1073/ pnas.0913048107
TAcconi, L. (2007) Decentralization, forests, and livelihoods: theory and narrative. Global Environmental Change, 17, 338348.

Toni, F. \& Kaimowitz, D. (eds) (2003) Municípios e gestão florestal na Amazônia. AS Editores, Natal, Brazil.

\title{
Governance and REDD: a reply to Wunder
}

\author{
Arun Agrawal, Fred Nelson, William M. Adams and Chris Sandbrook
}

$\mathrm{W}$ e welcome Wunder's (2010) response to our article (Sandbrook et al., 2010). Both contributions agree that too little attention has been devoted in international negotiations and discussions to the design and governance aspects of effective, efficient and equitable mechanisms for reducing emissions from deforestation and forest degradation (REDD). Such attention is urgently needed and some devolution, in the form of conditional rights to local communities and authorities, is better than centralized governance or complete devolution. Wunder also agrees with us that decentralization policies have been prompted by reactions against near-complete centralized control exercised by governments who have expropriated forests from people. But few governments, if any, have given up control over forests entirely. As Wunder recognizes, decentralization has typically been incomplete, even when its implementation is tested against the letter of adopted laws and policies (Ribot et al., 2006). We do not argue for complete decentralization (as Wunder believes we do) so much as urge caution against the risk that REDD interventions will reverse decentralization.

Wunder questions the extent to which existing studies of decentralization that point to the positive effects of securing local rights over forests, in particular studies produced by the International Forestry Resources and Institutions (IFRI) research programme, are relevant to the extensive agriculture/forest frontier. Here we disagree. The IFRI research programme provides perhaps the only systematically collected social, ecological and institutional data on local forest use and governance from across multiple country contexts. Its findings are essential to any understanding of forest governance. In showing that local institutions can be effective against deforestation even in contexts that are characterized by high population and market pressures for subsistence forest products, IFRI studies point to the potential benefits such institutions can create for improved forest outcomes on the extensive

Arun Agrawal School of Natural Resources and Environment, University of Michigan, Ann Arbor, Michigan, USA

Fred Nelson Maliasili Initiatives Ltd, Arusha, Tanzania

William M. Adams and Chris SANDBrook (Corresponding author) Department of Geography, University of Cambridge, Cambridge, CB2 3EN, UK. E-mail cgsandbrook@gmail.com forest margin where both these pressures are often attenuated. The key point is that attempts to reverse deforestation on the extensive forest frontier need macro-policy reforms but that such reforms can be strengthened if policy makers also attend to micro-level forest governance by creating strong local forest management institutions.

Wunder's suggestion that 'REDD will reinforce decentralization and devolution of rights, as states recognize they cannot effectively reduce deforestation by centralization alone,' is mostly the expression of a hope, and concedes one of our major points. The idea that REDD will reinforce decentralization is contradicted by evidence from many countries. It is no accident that $85 \%$ of forests are under formal government ownership (White \& Martin, 2002). Groups and individuals that comprise governing regimes have only conceded control over forest lands when pushed to do so by internal or external political or fiscal pressures. In eight of Africa's most-forested countries $98 \%$ of all forests are still formally owned by central governments, a situation that is hard to defend on grounds of technical efficiency, conservation or livelihoods (RRI, 2009).There is ample evidence that increasing natural resource values in African countries leads to politically-motivated recentralization over resources at the expense of those wider interests (Nelson \& Agrawal, 2008). Greater efficiency, by itself, is seldom the raison d'etre of government policies: governments seldom go out of business because they are inefficient.

Past experience of payment for ecosystem services projects is inadequate for thinking about how governments will alter existing forest governance strategies and policies. The available evidence is limited and Wunder (2010) does not provide much additional support for the proposition that payment for ecosystem services contributes to decentralization, or at least does not create incentives for recentralization. Importantly, revenues through potential REDD payments are astronomically larger than for existing payment for ecosystem services projects. When anticipated REDD payments exceed the budget of a government forestry department (as is the case, for example, for Indonesia and Guyana), and subsequent tranches depend on delivering improvements, it is highly unlikely that forestry agencies will risk such payments by depending on a multitude of third parties. 
Wunder also challenges us in stating that 'political economies in REDD recipient countries are too diverse to predict singular outcomes'. This is surely correct: the purpose of our article is to highlight the reality that forest governance institutions, particularly in contexts where governance is weak and rights over land and resources are easily changed or manipulated, are themselves subject to influence by the emergence of new markets for forest products. In the case of REDD there is little doubt that making forest carbon a multi-billion-dollar industry will create new incentives for claims over forest lands, and that the potential for such a scramble for control over forests is likely to lead to higher conflicts and lower incentives for forest stewardship than REDD initiatives are depending upon.

Contests over the new value and benefits of forest carbon will certainly play out differently depending on political-economic contextual variations, in particular variations in the capacity of local bodies to demand compensation for conservation services provided, to enforce their rights and to negotiate with others. For example, there is a dramatic difference between the ability of local forest users and residents to demand formal recognition of rights and participation in negotiations over REDD in, for example, Brazil compared to the Democratic Republic of Congo. But our point is that without careful attention to governance, as is currently the case, proposed REDD interventions will create incentives that undermine local interests and thereby REDD objectives. Instead of hoping that the context will help deliver positive outcomes, advocates of REDD can tilt the balance towards more positive outcomes by focusing more carefully, systematically and effectively on the governance of REDD. It is critical that the policy makers designing REDD attend to the political-economic implications of introducing new carbon markets, the importance of institutional factors to REDD outcomes, and the safeguards needed to ensure that payments under REDD translate into long-term incentives for improved forest management at different scales.

\section{References}

Nelson, F. \& Agrawal, A. (2008) Patronage or participation? Community-based natural resource management reform in subSaharan Africa, Development and Change, 39, 557-585.

Ribot, J., Agrawal, A. \& Larson, A. (2006) Recentralizing while decentralizing: how national governments reappropriate forest resources. World Development, 34, 1864-1886.

RRI (Rights AND Resources Initiative) (2009) Who Owns the Forests of Africa? An Introduction to the Forest Tenure Transition in Africa, 2002-2008, RRI, Washington, DC, USA.

Sandbrook, C., Nelson, F., Adams, W.M. \& Agrawal, A. (2010) Carbon, forests and the REDD paradox. Oryx, 44, 330-334.

White, A. \& Martin, A. (2002) Who Owns the World's Forests? Forest Trends, Washington, DC, USA.

W Under, S. (2010) Forest decentralization for REDD? A response to Sandbrook et al.. Oryx, 44, 335-337. 